\title{
THE DRIED DISC TECHNIQUE WITH BACITRACIN, CARBOMYCIN, ERYTHROMYCIN, POLYMYXIN B, AND TETRACYCLINE
}

\author{
BY \\ R. W. FAIRBROTHER AND R. C. JENNINGS \\ From the Department of Clinical Pathology, Manchester Royal Infirmary
}

(RECEIVED FOR PUBLICATION SEPTEMBER 27, 1954)

The bacteriological control of antibiotic therapy is becoming increasingly important in view of the steady production in the U.S.A. of potent new antibiotics, some of which have a limited range of activity. It is therefore necessary to have a rapid and reliable method of carrying out the sensitivity tests in order to make this a practical routine procedure.

The dried disc technique gives satisfactory results with penicillin, streptomycin, chloramphenicol, chlortetracycline (aureomycin), and oxytetracycline (terramycin) and is now widely used. It is therefore desirable that the range of discs should be extended to include bacitracin, carbomycin (magnamycin), erythromycin, polymyxin, and tetracycline.

\section{Technique}

The preparation of the dried discs followed closely the technique with the established antibiotics (Fairbrother and Martyn, 1951). Discs $(8 \mathrm{~mm}$. diameter) were punched from coloured blotting paper (Ford) and sterilized for one hour in the hot air oven at $150^{\circ} \mathrm{C}$. The discs were then carefully impregnated with one drop of freshly prepared solutions of the different antibiotics, using a " 50-dropper" pipette, and then dried for one and a half to two hours in the incubator, after which they were stored in sterile screw-cap bottles $(1 \mathrm{oz}$. at $0^{\circ}$ to $4^{\circ} \mathrm{C}$. (Table I).

TABLE I

PREPARATION OF THE DRIED DISCS

\begin{tabular}{|c|c|c|c|c|}
\hline Antibiotic & . & $\begin{array}{l}\text { Colour of } \\
\text { Disc }\end{array}$ & \begin{tabular}{|c|} 
Strength of \\
Solution per $\mathrm{ml}$
\end{tabular} & $\begin{array}{l}\text { Final Amount } \\
\text { on Disc }\end{array}$ \\
\hline $\begin{array}{l}\text { Bacitracin } \\
\text { Carbomycin } \\
\text { Erythromycin } \\
\text { Polymyxin B } \\
\text { Tetracycline }\end{array}$ & $\begin{array}{l}\ldots \\
\cdots \\
\cdots \\
\cdots\end{array}$ & $\begin{array}{l}\text { Blue } \\
\text { Grey } \\
\text { Red } \\
\text { Yellow } \\
\text { Purple }\end{array}$ & $\begin{array}{l}500 \text { units } \\
500 \mu \mathrm{g} . \\
500 \mu \text {. } \\
25,000 \text { units } \\
500 \mu \mathrm{g} .\end{array}$ & $\begin{array}{l}10 \text { units } \\
10 \mu \mathrm{g} . \\
10 \text {, } \\
500 \text { units } \dagger \\
10 \mu \mathrm{g} .\end{array}$ \\
\hline
\end{tabular}

* $1 \mathrm{mg}$. (bacitracin) $=50$ units (approx.)

$\dagger 1 \mu \mathrm{g} .($ polymyxin $)=7-10$ units.
Plates of appropriate media (agar, blood-agar, or chocolate-agar) were seeded either by flooding with a young broth culture or with the platinum loop to give a heavy, uniform, and pure growth. The discs were then added at regular intervals and readings were made after incubation at $37^{\circ} \mathrm{C}$. for 18 hours. In the case of rapidly growing bacteria, readings can often be made earlier. For comparative purposes, a zone of inhibition of $14 \mathrm{~mm}$. in diameter was considered to indicate sensitivity to the particular antibiotic.

The final strength of the various antibiotic solutions was determined by previous experience with the standard antibiotics and also by direct comparison with the results given by the serial dilution technique; consideration was also given to the tissue levels resulting from routine therapeutic practice.

\section{Results}

The new antibiotics differ considerably in their range of antibacterial activity, and in consequence they have been arranged arbitrarily, for convenience of discussion and comparison with established antibiotics, into three groups: (1) erythromycin, carbomycin, and bacitracin-acting mainly on Gram-positive cocci; (2) tetracycline with a wide range of activity; (3) polymyxin B-effective against some Gram-negative bacilli, in particular $P s$. pyocyanea.

A wide variety of organisms was included in the test series; all were active pathogens freshly isolated from infective processes. Initially the new antibiotics were added to duplicate plates of the test organism, but later all discs were added to the same plate. This procedure, involving seven or eight discs per plate, proved satisfactory provided the discs were carefully spaced. It is now the routine practice.

Group I.-Carbomycin was originally included in this series, but it was eventually omitted, as unsatisfactory clinical trials were reported in the U.S.A. (Finland, 1953). The results are presented 
together with those given by penicillin, which has a comparable antibacterial spectrum (Table II). In all cases the various antibiotics were tested simultaneously against the individual organisms.

TABLE II

SENSITIVITY OF COMMON PATHOGENS TO ERYTHROMYCIN, CARBOMYCIN, BACITRACIN, AND PENICILLIN BY DISC TECHNIQUE

\begin{tabular}{|c|c|c|c|c|c|}
\hline \multirow[b]{2}{*}{ Organism } & \multirow{2}{*}{$\begin{array}{l}\text { No. } \\
\text { Tested }\end{array}$} & \multicolumn{4}{|c|}{ Percentage Sensitive } \\
\hline & & $\begin{array}{l}\text { Peni- } \\
\text { cillin }\end{array}$ & $\begin{array}{l}\text { Erythro- } \\
\text { mycin }\end{array}$ & $\begin{array}{c}\text { Baci- } \\
\text { tracin }\end{array}$ & $\begin{array}{l}\text { Carbo- } \\
\text { mycin }\end{array}$ \\
\hline Staph. aureus & 300 & 43 & $99 \cdot 7$ & 100 & $\begin{array}{r}100(12 y \\
\text { tested })\end{array}$ \\
\hline $\begin{array}{l}\text { Strep. haemolyticu } \\
\text { (Group A) } \\
\text { Strep. haemolyticu }\end{array}$ & 32 & 100 & 100 & 100 & \\
\hline (other groups) & 25 & 100 & 100 & 100 & \\
\hline $\begin{array}{l}\text { Strep. fuecalis } \\
\text { Pneumococcus }\end{array}$ & 65 & $13 \cdot 8$ & 100 & 100 & \\
\hline $\begin{array}{l}\text { Pneumococcus } \\
\text { Coliforms }\end{array}$ & 17 & 100 & 100 & 100 & \\
\hline $\begin{array}{l}\text { Coliforms } \\
\text { Proteus }\end{array}$ & 110 & 0 & 0 & 0 & \\
\hline $\begin{array}{l}\text { Proteus } \\
\text { Ps. pyocyanea }\end{array}$ & 80 & 0 & 0 & 0 & \\
\hline $\begin{array}{l}\text { Ps. pyocyanea } \\
\text { H. influenzae and } H\end{array}$ & 70 & 0 & 0 & 0 & \\
\hline $\begin{array}{c}\text { H. influenzae and } H \\
\text { parainfluen ae }\end{array}$ & J & 34 & 100 & 0 & \\
\hline Monilia albicans & 15 & 0 & 0 & 0 & \\
\hline
\end{tabular}

Erythromycin, carbomycin, and bacitracin proved remarkably effective against the Gram-positive cocci, irrespective of their reaction to penicillin; sharply defined zones of inhibition were produced. Several strains of Staph. aureus, isolated from unrelated infections, proved resistant to the established antibiotics but sensitive to erythromycin and bacitracin. At the end of this series, a resistant strain of Staph. aureus, isolated from an infected wound, gave a clear zone of inhibition with bacitracin and only an indefinite zone with erythromycin. Tests were consequently carried out with individual colonies from the primary culture; the erythromycin discs gave a slight and indefinite zone of inhibition and the organisms were only inhibited by 8 to $64 \mu \mathrm{g}$. $\mathrm{ml}$. in the serial dilution test.

Erythromycin, but not bacitracin, was also effective against the influenza and parainfluenza bacilli. The coliform, Proteus, Ps. pyocyanea, and Monilia strains invariably proved resistant.

Group II.--Tetracycline has a chemical structure closely related to chlcrtetracycline (aureomycin) and oxytetracycline (terramycin), from which it was originally prepared. A similar, but not identical, antibacterial spectrum has been reported and differences in stability and toxicity have been observed (Finland, 1953). These products are ciosely related and have been grouped together.

Stability tests on solutions of the three antibiotics $\left(128 \mu \mathrm{g}\right.$. $\mathrm{ml}$.) were carried out at $4^{\circ} \mathrm{C}$. and room temperature. In both series chlortetracycline proved to be least stable, with oxytetracycline slightly more stable than tetracycline.
Disc sensitivity tests were carried out under $\stackrel{\stackrel{0}{*}}{\frac{0}{*}}$ strictly comparable conditions on a number of $\frac{\text { ? }}{\%}$ common pathogens; the results are given in $\overrightarrow{\vec{s}}$ Table III.

The results indicate that these analogues have a? comparable, but not identical, range of antibacterial $\frac{\bar{\sigma}}{\bar{c}}$ activity. Some bacteria, particularly gram-negative $\frac{\widehat{\Phi}}{2}$ bacilli, exhibited marked differences in their reaction $\cong$ to the three compounds when tested by the discos techniques. These results were confirmed, in $\mathrm{a} \vec{\circ}$ number of instances, by the serial dilution tests.

TABLE III

SENSITIVITY OF COMMON PATHOGENS TO CHLORTETRACYCLINE, OXYTETRACYCLINE AND TETRACYCLINE BYO

\begin{tabular}{|c|c|c|c|c|}
\hline \multirow[b]{2}{*}{ Organism } & \multirow{2}{*}{$\begin{array}{l}\text { No. } \\
\text { Tested }\end{array}$} & \multicolumn{3}{|c|}{ Percentage Sensitive } \\
\hline & & $\begin{array}{c}\text { Chlortetra- } \\
\text { cycline }\end{array}$ & $\begin{array}{l}\text { Oxytetra- } \\
\text { cycline }\end{array}$ & $\begin{array}{l}\text { Tetra- } \\
\text { cycline }\end{array}$ \\
\hline Staph. aureus & 250 & 92 & 92 & 92 \\
\hline $\begin{array}{l}\text { Strep. haemolyticus } \\
\text { (Group A) }\end{array}$ & 32 & 100 & 100 & 100 \\
\hline $\begin{array}{l}\text { Strep. haemo!yticus } \\
\text { (other groups) }\end{array}$ & 25 & 100 & 100 & 100 \\
\hline Strep. faecalis & 60 & 60 & 61 & 61 \\
\hline Pneumococcus & 17 & 100 & 100 & 100 \\
\hline Coliforms & 105 & 84 & 92 & 85 \\
\hline Proteus & 75 & $10 \cdot 8$ & $10 \cdot 8$ & $9 \cdot 3$ \\
\hline Ps. pyocyanea & 70 & $4 \cdot 3^{*}$ & $15^{*}$ & $2 \cdot 8 *$ \\
\hline Friedländer's bacillus & 8 & 75 & 100 & 75 \\
\hline $\begin{array}{c}H \text {. Influenzae and } H \text {. } \\
\text { parainfluenzae }\end{array}$ & 32 & 100 & 100 & 100 \\
\hline Monilia albicans & 15 & 0 & 0 & 0 \\
\hline
\end{tabular}

Group III.--Although the polymyxins, in $\overrightarrow{\overrightarrow{0}}$ particular aerosporin, were isolated some time ago,, they have not been widely used for therapeutic purposes because of their toxic effects. The toxicity? has been reduced and, as infections with $P s \bar{\Omega}$ pyocyanea do not respond readily to the othe? antibiotics, there is now an increasing demand for polymyxin B, particularly for local application.

A number of tests have been carried out and thes results are compared with those given by streptomycin and chloramphenicol under strictly? comparable conditions (Table IV).

TABLE IV

SENSITIVITY OF SOME PATHOGENS TO STREPTOMYCINO CHLORAMPHENICOL, AND POLYMYXIN B BY DISG

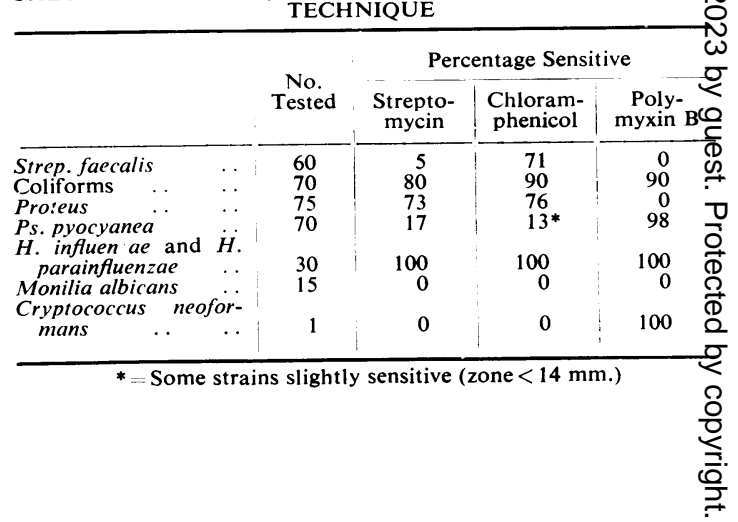


These results indicate clearly the effectivenesss of polymyxin against Ps. pyocyanea; by th? tube technique, it was found that 65 out of 66 strains were inhibited by concentrations of 4 to 16 units $/ \mathrm{ml}$., and one out of 66 strains by 128 units $/ \mathrm{ml}$. While these concentrations are relatively high, many of these strains were isolated from superficial lesions, such as infected burns and wounds as well as chronic otitis, in which direct application of the antibiotic is readily accomplished.

It is interesting to note that, while $15 / 15$ strains of Monilia were resistant to all antibiotics, a strain of Cryptococcus neoformans, isolated from a fatal infection, proved to be resistant to all antibiotics except polymyxin, which gave a clear zone of inhibition by the disc technique and a tube sensitivity of 16 units' $\mathrm{ml}$.

\section{Discussion}

The dried disc technique has proved a satisfactory routine method of determining the sensitivity of the common pathogens to the new antibiotics. It is a rapid qualitative test which provides useful information to guide the selection of a potentially effective product for therapeutic purposes.

The best results are given by pure cultures prepared from the primary culture of the infected material, but under certain circumstances, particularly when a heavy pure growth seems probable, useful information may be obtained by the addition of the discs to the primary culture. A duplicate plate should always be used for this purpose. Whenever equivocal results are given, further tests should be done with the serial dilution technique.

Erythromycin and bacitracin are very effective against gram-positive cocci and they should be especially useful in the treatment of infections caused by penicillin-resistant staphylococci. Caution is, however necessary, as bacteria tend readily to develop resistance to erythromycin; several resistant strains of Staph. aureus have been isolated since the completion of this series.

Tetracycline has a wide range of activity, which is similar, but not identical, to that of the other tetracycline compounds, aureomycin and terramycin. Tetracycline must therefore be treated as a distinct antibiotic and not merely as a substitute for established products.

Polymyxin B proved very effective against $P s$. pyocyanea and also against one strain of Cryptococcus neoformans. It is particularly useful for direct local application.

\section{Summary}

The dried disc technique has proved a useful method of testing the activity of erythromycin, bacitracin, carbomycin, tetracycline, and polymyxin B. It has given satisfactory results with a wide range of common pathogens. The results have been compared with those given by the standard antibiotics.

We wish to thank Messrs. Lederle Laboratories Division, Pfizer, Ltd., Eli Lilly \& Co., Ltd., and Abbotts Laboratories, Ltd., for special supplies of tetracycline (achromycin), carbomycin, erythromycin (ilotycin and erythrocin) respectively: also Dr. J. Davson for the culture of Cryptococcus neoformans.

\section{REFERENCES}

Fairbrother, R. W., and Martyn, G. (1951). Journal of Clinical Pathology, 474

Finland, M. (1953). Brit. med. J., 2, 1115. 